\title{
Factors that Influence Online Learning Assessment and Satisfaction: Using Moodle as a Learning Management System
}

\author{
Hongjiang $\mathrm{Xu}^{1} \&$ Sakthi Mahenthiran ${ }^{1}$ \\ ${ }^{1}$ College of Business, Butler University, Indianapolis, USA \\ Correspondence: Hongjiang Xu, College of Business, Butler Univesity, 4600 Sunset Ave., Indianapolis, IN \\ 46208, USA. E-mail: hxu@butler.edu
}

Received: November 30, 2015

Accepted: December 22, 2015

Online Published: January 25, 2016

doi: 10.5539/ibr.v9n2p1

URL: http://dx.doi.org/10.5539/ibr.v9n2p1

\begin{abstract}
Higher education continues to evolve, including recent increases in the number of courses offered fully and partially (hybrid) online. Many new technologies have been used to support online education, particularly learning management systems (LMS's), which serve as the core technology platforms for the online environment. Our research is to use Moodle as an LMS and empirical survey data to investigate what are the factors that influence online assessment and overall satisfaction with online learning. We used an online survey as the method of data collection for this study. The survey questionnaire was sent anonymously to all students who took the online or hybrid course sections at a US university, as well as all faculty who taught those online or hybrid course sections. The research result showed that overall student satisfaction with online learning is significantly affected by how the course is organized and how the content is sequenced, the ease with which students can complete assignments, and the use of the LMS to engage with content.
\end{abstract}

Keywords: online learning, assessment, student satisfaction, learning management systems, moodle

\section{Introduction}

According to Allen and Seaman (Allen \& Seaman, 2013), the Sloan Online Survey found that in 2002 less than half of U.S. higher education institutions reported online education as being critical to their long-term strategy. However, in 2012, 70\% of the surveyed academic leaders saw online learning (or e-learning) as critical to their long-term strategy. The 2012 report showed that there were 6.7 million students (32\% of the total student population in the U.S.) taking at least one online course. Furthermore, $77 \%$ of academic leaders rated the learning outcomes in online education as the same or superior to face-to-face instruction. Nevertheless, no more than one-third of chief academic officers reported that their faculty accepted the value and legitimacy of online education. The barriers that affect the growth of online education are a lack of discipline on the part of online students, lower retention rates for online courses, and a lack of acceptance of online degrees by potential employers (Allen \& Seaman, 2013). We believe if these questions are to be addressed first it is important to study how to effectively assess student learning and understand what factors influence student and faculty satisfaction with online learning. In particular, from students' perspectives, their online learning experiences might relate to the technology platform, online assessment activities, and satisfaction of the overall online learning environment.

Higher education continues to evolve, including recent increases in the number of courses offered fully and partially (hybrid) online. Colleges and universities continue to increase their online course offerings and in the university where this study was conducted, they are planning to increase their online offerings for at least some of their programs such as for the MBA program. In order to offer these courses, it is important to have an effective technology platform to support the online class environment and activities. Many new technologies have been used to support online education, particularly learning management systems (LMS's), which serve as the core technology platforms for the online environment. Some popular systems include Blackboard, Moodle, Sakai, Desire2Learn, Canvas, and eCollege. Moodle as an open technology platform is emerging as the most cost effective solution.

A LMS is one of the most representative e-learning applications that can be an open source and freely available software, while others are commercial products. The LMS is used for online education as well as to supplement face-to-face courses. The LMS is commonly used to post a course's syllabus and announcements, homework 
assignments and projects, and lecture notes and slides for students to access online (ODCD, 2005). There is a strong movement toward open-source solutions (away from proprietary software) for e-learning applications (Coppola \& Neelley, 2004). Open-source software provides flexibility to combine languages, scripts, learning objects, and lesson plans without the steep cost of proprietary packages (Williams, 2003). Moodle is an example of such an open-source LMS, and is the platform that is the subject of our study.

Learning management systems support many important functions for effective online education, including facilitating instruction, assessment, course administration and providing a new means for communication with students. One study shows that the perceived flexibility of the delivery medium is significantly associated with students' perceived learning and satisfaction of the online program (Arbaugh \& Duray, 2002). To create a solid foundation for successful online education, it is critical for universities to measure how well the systems they use deliver on these key functions and support the online learning environment to serve their core academic mission. The use of new technologies and the application of new educational models need to be supported by systematic redesign of the processes at both the institutional and educator levels (Georgouli, Skalkidis, \& Guerreiro, 2008). Hence, there is a need to understand factors that affect student satisfaction with online education and the effectiveness of the technical platform as an effective learning and communicating tool. In particular, there are challenges related to online assessment activities, such as the level of monitoring to inhibit cheating on exams taken online, which appears to be of greater concern among educators than the problem of cheating in traditional face-to-face coursework. Therefore, our study investigates the factors that influence student assessment and overall student and faculty satisfaction with online courses in regard to their technology platform, in this case the Moodle learning management system.

\section{Literature Review}

Online learning is rapidly growing in society today; however, there are many variables that help explain the contrasts between online and traditional face-to-face learning as well as how they influence student satisfaction. According to Sun et al. (Sun, Tsai, Finger, Chen, \& Yeh, 2008), some of the factors that influence student satisfaction with online learning systems include: Computer/technology anxiety on the part of the learner, instructor attitudes toward e-learning, course flexibility and quality, perceived usefulness of the LMS and ease of use, and the diversity in assessment methods. According to Georgouli et al. (2008), online content should be complemented and enhanced through activities (e.g., blog, discussion board, etc.) to facilitate self-learning. Additionally, according to Selim (2005), instructors of online courses need to have a positive attitude towards the technology, and the students should have competent computer skills. Consequently, one of the biggest challenges with online learning is that students and instructors may lack the knowledge or skills required to use an online learning management system for the first time. A poor first experience can scare students away from online learning in the future (Georgouli et al., 2008).

Student satisfaction with online learning is also influenced by students' perceived beliefs about the systems' effectiveness. Hence, implementation of online courses should focus on factors that contribute to students' success and strengthen their adoption. A study based on the in-depth interviews with graduate and undergraduate students revealed fundamental pedagogical principles for enhancing student learning through the use of the technology platform: Student-to-student connectivity, instructor-to-student interactivity, goal efficiency, quality content, and student appeal (Hollenbeck \& Mason, 2011). According to Bell and Federman (Bell \& Federman, 2013), online learning should provide content, immersion, interactivity, and effective communication. Course structure, instructor feedback, self-motivation, learning style, interaction, and instructor facilitation can affect students' perceived satisfaction of online learning (Eom, Wen, \& Ashill, 2006). By focusing on the factors that affect student satisfaction, online learning systems can be improved and implementation strengthened to increase the learner satisfaction and retention of the material.

Although there are some similarities between face-to-face and online education assessment activities, there are many differences in terms of approaches, focus, and technology advantages as well as challenges. Traditional face-to-face student assessment focuses on retention of specific knowledge and its application in limited contexts; these are commonly measured using quizzes, tests, exams, and academic projects as well as assignments. Increasingly, there are also alternative assessment methods that aim to improve higher-order thinking skills and educational objectives (i.e., deeper understanding of the material through the active use of the knowledge in more realistic and complex contexts). According to Reeves (2000), there are different approaches to incorporate these alternative assessments into online education, such as cognitive, performance, and portfolio assessments.

Stacey and Wiesenberg (2008) noted the importance of key variables, such as length of time teaching face-to-face and online, overall teaching load, class size, and institutional context, which affect faculty members' 
motivation and attitudes towards moving from traditional to virtual classrooms. The results of their research have implications for the professional development of teachers making the transition to online teaching. Most notably, the research indicates that "it is important to ensure 'early adopters' are encouraged to [lead the way] by an accompanying reduction in their teaching load and classroom sizes, at least while they gain expertise in [teaching online]" (p. 76). As a result, institutional context (e.g., voluntary versus mandatory use, level of professional development and technical support, and overall implementation and design of the learning system) is a key variable to achieving success with online learning. In fact, Naveh et al. (2010) found significant correlation between LMS use and student satisfaction in terms of similar organizational variables, which included class size, course content, instructor status, and the existence of forums. Given that a properly implemented and supported online learning system can help students' and instructors' initial online experiences run more smoothly and ease the transitions from face-to-face classrooms to virtual learning, it is important to systematically study the factors that influence successful adoption of online learning.

Online learning presents an array of challenges and issues to faculty who depend on technology systems to completely deliver or support their courses. According to Dermo (2009), there are concerns about the validity, practicality, and reliability of online student assessment, in addition to concerns about the security of the online platform itself. The validity of online assessments concerns whether the tasks are appropriate for the student audience. Practicality refers to the practical challenges and benefits of online assessments, while reliability focuses on the accuracy of online assessments (Dermo, 2009). Further, one of the more critical issues for online learning is security. Security concerns can encompass questions about whether users of the system are legitimate students or teachers, the authenticity of the students eligibility to access specific course contend, and overall accessibility (Alwi \& Fan, 2010). Moreover, Alwi and Fan are not alone in pointing out the vulnerability of online information to compromise, whether from data corruption, manipulation, or outright theft. Additional issues may relate to academic honesty, as students can have a more relaxed attitude towards cheating in online settings as compared to a traditional face-to-face environment. According to a study at the University of West Florida, $73.6 \%$ of students believed that it was easier to cheat in an online course than in a face-to-face course (King, Guyette, \& Piotrowski, 2009).

According to decades of research, good teaching (regardless of whether it is delivered online or face-to-face) involves, among other things, providing an opportunity for student-faculty interaction, active learning, and prompt feedback. Yet, in the online environment, interactions, learning, and feedback often require unique strategies due to the affordances and challenges presented by technology-mediated teaching. Barran, Correia, and Thompson (2011) stated it as follows:

The online environment changes the fundamental nature of the interaction between the teacher, student, and content, requiring a re-examination of the roles teachers take in enhancing students' learning. Because online students are expected to take greater control of their learning process and be more active in stimulating their peers' learning, facilitation of online learning emerges as an important role in guiding these student-centered approaches. Moreover, as the hierarchy in the online environment is flattened with more distributed power and control (Schrum \& Hong, 2002), teachers are expected to adopt more facilitative approaches in creating learner-centered online classrooms (Salmon, 2004; Smith, 2005). While there is still a strong focus on the responsibilities of teachers in online courses, the teacher moves from being at the center of the interaction or the source of information to the "guide on the side," which implies that teachers design, organize, and schedule the activities and learners assume greater responsibility for their learning by coordinating and regulating their learning activities (Anderson, Rourke, Garrison, \& Archer, 2001; Berge, 2009) (p. 429).

This notion that teaching online requires the development of new skills and sets of pedagogies has led researchers to study the roles that online instructors take in online education environments (Anderson et al., 2001; Berge \& Collins, 2000; Goodyear, Salmon, Spector, Steeples, \& Tickner, 2001; Graham, Cagiltay, Lim, Craner, \& Duffy, 2001; Guasch, Alvarez, \& Espasa, 2010; Salmon, 2004). When designing online courses, it is important to consider the format and effectiveness of student assessment. Technology is ever changing, and the use of online assessments should continue to evolve to fit students' needs, and to ensure safety and security. Countermeasures, such as security technology hardware and software implementation, are being developed to increase the availability and integrity of information provided in online learning assessments (Alwi \& Fan, 2010). Additionally, educators should spell out academic standards to decrease academic dishonesty, and construct online assessments in a way that encourages honesty (King et al., 2009). For example, educators can provide frequent, but short, intensive essay questions in place of multiple-choice questions. The use of assessment rubrics for student assessments would make assessment activities more reliable and valid to encourage engagement and to provide more formal measures of achievement (Oncu \& Cakir, 2011). 
The interaction between students and instructors is an important factor for online learning. As compare to face-to-face learning, there is lack of real physical person to person connections in online learning environment. Therefore, it is critical to create effective online interaction to enhance the communication of online learning. The 'Active Mastery Learning' is an online instructional design theory that emphasizes the importance of creating team based learning environment where learner-learner, learner-instructor, and learner-content interactions are monitored to provide students feedback about the progress they are making in online learning (Puzziferro \& Shelton, 2008). A study of a web-based videoconferencing tool for synchronous learning sessions showed that learner-instructor interaction and learner-learner interactions were the significant predictors of student satisfaction; this same study also showed that tools that have features such as emotions icons, talk, or raise hand functions could help students interact with the instructor (Kuo, Walker, Belland, Schroder, \& Kuo, 2014). Another study of graduate and undergraduate students' online learning results showed that learner-instructor interaction and learner-content interaction have significant impact on student satisfaction (Schroder \& Belland, 2014).

\section{Research Hypotheses and Research Models}

Although some studies suggest factors that might influence online learning and assessment, many of these have not been empirically tested. Our research therefore sought to support the following two hypotheses using empirical survey data:

H1: Student satisfaction with online assessment is affected by their experience with the LMS, the ease of accessing the functionalities of the LMS, and the interaction between instructors and students.

H2: Overall student satisfaction with online learning is affected by the extent of online assessment activities, experience with the LMS, the ease of accessing the functionalities of the LMS, and the interaction between instructors and students.

\subsection{Research Models}

Two generic research models were developed to help test the two proposed research hypotheses.

The first model used satisfaction of assessment tools in the LMS as the dependent variable and explanatory factors (course content, communication and collaborations, overall LMS experience, and training), and control variables (gender, student's class standing, GPA, host institution) as the independent variables.

Satisfaction of online assessment $=$ constant + explanatory factors (course content, communication and collaborations, overall LMS experience, and training) + control variables (gender, class standing, GPA, and host institution)

The second model used the overall satisfaction experience of each respondent with using the LMS as the dependent variable, and the satisfaction of assessment (the dependent variable from model 1), explanatory factors (same as model 1), and control variables (same as model 1) as the independent variables.

Overall satisfaction of online learning $=$ constant + satisfaction of online assessment + explanatory factors (course content, communication and collaborations, overall LMS experience, and training) + control variables (gender, class standing, GPA, and host institution)

\section{Methodology}

We chose to use an online survey as the method of data collection for this study, as it is appropriate for a project that aims to investigate the factors that influence student satisfaction with online learning. The survey questionnaire was sent anonymously to all students who took the online or hybrid course sections at a US university in summer semesters where it was the first time the university had offered online or hybrid courses, as well as all faculty who taught those online or hybrid course sections. The design of the survey instrument was based on the existing literature and the proposed research models used to test our research hypotheses. All questions from the questionnaire are included in the Appendix. It includes measurements for the dependent variables, explanatory factor items, and control variables in our two research models. For the purpose of testing our hypotheses, data analysis is focused on the data collected from students. Additionally, we include summary responses from the faculty survey; these responses help to build the connections between the student and faculty perspectives.

\subsection{Sample}

The sample for the study included all 26 online or hybrid course sections taught during the summer term in a single private university. Approximately one quarter of the students were enrolled in accounting classes in the 
College of Business, another quarter were from the College of Liberal Arts and Sciences, and another quarter were from the College of Education. In total, 319 students were enrolled in those sections, and we received responses from 91 students, for a response rate of 27.7\%. However, a few questions from respondents about using the blog, chat, and Adobe Connect features of the LMS were incomplete or marked as "not applicable". Thus, to maximize the sample size for our analyses, we replaced the missing values for these variables with their mean values. There were in total 22 faculty who taught the online or hybrid course sections, and we received responses from 17 of them, for a response rate of $77.3 \%$.

\subsection{Variable Definitions}

A majority of the students agreed or strongly agreed with the following questionnaire statements (see Q26 to Q29 in the Appendix): (1) Moodle is straightforward and easy, (2) The organization and sequence of course was easy to navigate, (3) I am able to complete class assignments in Moodle, and (4) In the majority of my courses, I interact and do things with content rather than read/view the content. We were reassured by the fact that our participants had good experiences with Moodle and relied on it to complete their class assignments, including doing things beyond simply viewing documents. Further, we conducted a factor analysis for all the items in the questionnaire and found that there were four distinct constructs. Table 1 shows that these four items loaded together on a single factor in Component 1, which we refer to as the "Moodle Experience" labeled (M_Exp). In Table 1, in addition to the M_Exp construct, the Component 1 factor structure clearly shows that there is another distinct factor that captures the experience with accessing materials in Moodle (in the Appendix it's referred to as M_Access). M_Access and the other constructs derived from our confirmatory factor analysis, performed using principal components analysis and varimax rotation, provide us with the following results.

Table 1. Confirmatory factor analysis-principal components analysis with varimax rotation

\begin{tabular}{ccccc}
\hline Items & Component 1 & Component 2 & Component 3 & Component 4 \\
\hline Orient_M & 0.076 & 0.108 & -0.007 & 0.944 \\
Adequate_Orient & -0.013 & -0.018 & -0.069 & 0.940 \\
View_Grades & 0.429 & 0.209 & 0.656 & -0.126 \\
Access_Feedback & 0.268 & 0.259 & 0.824 & 0.007 \\
Turnitin_Comments & 0.172 & 0.288 & 0.832 & 0.002 \\
View_Folder & 0.813 & 0.349 & 0.213 & -0.014 \\
View_Web & 0.853 & 0.222 & 0.251 & 0.021 \\
Complete_Assign & 0.847 & 0.251 & 0.189 & 0.047 \\
Complete_Turnitin & 0.749 & 0.301 & 0.142 & 0.137 \\
View_Panopto & 0.612 & 0.418 & -0.022 & 0.020 \\
Take_Quiz & 0.584 & 0.181 & 0.316 & 0.263 \\
News_Forum & 0.496 & 0.469 & 0.356 & -0.102 \\
Discuss_M & 0.575 & 0.318 & 0.492 & -0.051 \\
Email_M & 0.427 & 0.558 & 0.440 & -0.051 \\
Chat_M & 0.282 & 0.694 & 0.361 & -0.003 \\
Wiki_M & 0.194 & 0.790 & 0.298 & 0.148 \\
Blog_M & 0.282 & 0.822 & 0.192 & 0.043 \\
Adobe_M & 0.289 & 0.724 & 0.127 & 0.038 \\
Straight_Forward & 0.662 & 0.220 & 0.417 & 0.003 \\
Course_Seq_Navigate & 0.751 & 0.116 & 0.365 & 0.010 \\
Complete_Assign & 0.743 & 0.121 & 0.223 & -0.036 \\
Interact_Do_Things & 0.491 & 0.296 & 0.063 & -0.053 \\
\hline & & & &
\end{tabular}

Rotation converged in 6 iterations. Four factors extract $71 \%$ of the variance. Kaiser-Meyer-Olkin Measure of Sampling Adequacy $=0.914$. Approx. Chi Square $=503.188$. Bartlett's Test of Sphericity. $\mathrm{df}=325$. Sig. $=0.000$

- Six questions about access to course content and two communication/collaboration questions (i.e., Q13-Q20 shown in the Appendix) loaded together on a single factor, which is labeled as M_Access. These items were viewing files/folders, viewing links to websites, completing assignments, completing Turnitin assignments, viewing Panopto video recordings, taking quizzes, communicating and collaborating with the news forum, and the use of forums for discussions. 
- The remaining five communication and collaboration items loaded together on a single factor as Component 2 in Table 1, which we labeled as M_Comm. These constructs included items such as messaging, using IM/e-mail, chat, wiki, blogs, and Adobe Connect.

- The M_Assess construct consists of three items shown as Component 3 in Table 1, and are related to conducting student assessment in Moodle. The first item measures the ease with which one can view grades, the second item measures the ease of accessing feedback on assignments, and the third question measures the ease with which one can view comments provided for assignments submitted via the Turnitin function of Moodle (see Q10-Q12 in the Appendix).

- Component 4 in Table 1 captures the adequacy of training provided to students, and we label it as "Train."

Table 2 shows that the "Train", "M_Assess", "M_Access" and "M_Comm" variables have high Cronbach Alpha scores (i.e., $0.91,0.89,0.95,0.96$, and 0.83 respectively), which is well above the acceptable reliability score of 0.70 (Nunally, 1970). Hence, we conclude that the scales we used are reliable. Our main dependent variable is a single questionnaire item measuring the overall satisfaction with Moodle (see Q30 in the Appendix). Additionally, we also use M_Assess as a dependent variable to examine which factors affect online assessment. Since the university offered voluntary Moodle training opportunities for its faculty and students, we control for familiarity with it using two questions (see Q8-Q9 in the Appendix and Component 4 in Table 1), which also loaded on a single factor (labeled as "Train"). Additionally, we control for students' gender, class standing, the college to which they belong, and their GPA.

Turnitin is a third-party (paid) plug-in that enhances the core Moodle system. Its digital plagiarism-detection utility gives teachers the ability to grade and check papers for plagiarism. Because plagiarism is a growing concern in education today, Turnitin is an effective way for instructors to check for it (Sutherland-Smith \& Carr, 2005). The system compares student work to papers, articles, and books from internal sources as well as other university systems and provides color-coded originality scores and reports for use by instructors (Dahl, 2007). The system also has many additional features; for example, Turnitin provides digital feedback, an online grade book, and attendance lists. Additional features such as anonymous peer reviews are expected to be possible in the future (Dahl, 2007).

\subsection{Models Analyzed}

The first model, below, used ease of assessment tools (M_Assess) in Moodle as the dependent variable and our explanatory and control variables as the independent variables. An OLS regression analysis was performed to report the results. The $\underline{i}$ subscript attached to each variable refers to the fact that response rates were obtained from separate students.

$$
\begin{aligned}
\text { M_Assess }_{\mathrm{i}}=\text { Constant }^{+} & \alpha_{1} \text { M_Access }_{\mathrm{i}}+\alpha_{2} \mathrm{M}_{-} \text {Comm }_{\mathrm{i}}+\alpha_{3} \mathrm{M}_{-} \text {Exp }_{\mathrm{i}} \\
& +\alpha_{4} \operatorname{Train}_{\mathrm{i}}+\alpha_{5} \text { Gender }_{\mathrm{i}}+\alpha_{6} \text { Standing }_{\mathrm{i}}+\alpha_{7} \text { GPA }_{\mathrm{i}}+\alpha_{8} \text { College }_{\mathrm{i}}+\varepsilon_{\mathrm{it}}
\end{aligned}
$$

The second model used the "Overall Satisfaction" experience of each student with using Moodle as the dependent variable, and our explanatory and control variables as the independent variables. Again, an OLS regression analysis was performed to report the results.

$$
\begin{aligned}
& \text { Overall Satisfaction }_{\text {it }}=\text { Constant }+\beta_{1} \text { M_Assess }_{i}+\beta_{2} \text { M_Access } \\
& \\
& +\beta_{4} \text { M_Exp }_{i}+\beta_{3} \text { M_Comm }_{i} \text { Train }_{i}+\beta_{6} \text { Gender }_{i}+\beta_{7} \text { Standing }_{i}+\beta_{8} \text { GPA }_{i}+\beta_{9} \text { College }_{i}+\varepsilon_{i t}
\end{aligned}
$$

\section{Results and Discussions}

\subsection{Quantitative Data-Student Survey Close-Ended Questions}

The descriptive results of the student survey indicate that most of our student respondents were female sophomore students taking summer classes offered by the College of Liberal Arts and Sciences or the College of Business. The students typically took two or three courses over two summer sessions, and most of their courses used Moodle, which they valued (i.e., felt it was important) in their classes. In terms of how students used Moodle, $68.2 \%$ felt it was straightforward and intuitive, $75.9 \%$ found it was easy to navigate, and $85.8 \%$ reflected that it enabled them to easily complete class assignments. Overall, only $11.3 \%$ were dissatisfied after using Moodle for these courses (70.8\% satisfied and $18 \%$ neutral). It is worth noting that even though the majority of students' comments indicated that Moodle was easy to use, only $17.6 \%$ of the students received Moodle training.

In comparing a subsection of student data across the different colleges, there were 19 students from an 
introductory accounting course within the College of Business whose findings were similar. In terms of how these students used Moodle, $66.6 \%$ felt it was straightforward and intuitive, $73.3 \%$ found it easy to navigate, and 93.4\% reflected that it enabled them to easily complete class assignments. Overall, only $13.4 \%$ of the students within this subsection were dissatisfied after using Moodle for these courses (60\% satisfied and $26.7 \%$ neutral). As with the majority of their peers, only $20 \%$ of these students received Moodle training.

In comparing another subsection of student data (72 students who did not receive an orientation to Moodle), the findings were consistent with the findings from the College of Business students. In terms of how these students used Moodle, $66.6 \%$ felt it was straightforward and intuitive, $76.4 \%$ found it easy to navigate, and $90.0 \%$ reflected that it enabled them to easily complete class assignments. Overall, only $10 \%$ of the students within this subsection were dissatisfied after using Moodle ( $71.5 \%$ satisfied and $18.6 \%$ neutral).

Table 2 shows that the mean score for "Overall Satisfaction" was 2.2 (where a score of 1 is very satisfied, 2 is satisfied, and 3 is neutral), and the majority of students felt it was easy or very easy to view grades and access assignment feedback in Moodle (labeled M_Assess in the Appendix). Nevertheless, only 43\% of students felt the OLS was easy or very easy to use when the written assignments were submitted via the Turnitin functionality. The range of this response distribution resulted in an average score of 3.5 out of 5 for the M_Assess variable.

Table 2. Descriptive and reliability statistics

\begin{tabular}{ccccc}
\hline Variables & Mean & Std. Deviation & No. Items & Cronbach Alpha \\
\hline Overall Satisfaction & 2.20 & 1.03 & 1 & 0.91 \\
Train & 1.81 & 0.38 & 2 & 0.89 \\
M_Assess & 3.54 & 1.15 & 3 & 0.95 \\
M_Access & 3.94 & 0.92 & 8 & 0.96 \\
M_Comm & 3.32 & 1.03 & 5 & 0.83 \\
M_Exp & 3.90 & 0.80 & 4 & \\
Gender & 1.77 & 0.42 & 1 & \\
Standing & 2.91 & 0.97 & 1 & \\
GPA & 5.46 & 0.87 & 1 & \\
College & 3.44 & 1.85 & 1 & \\
\hline
\end{tabular}

Note. Labels are described in the Appendix. Sample size used to calculate all the means is 91.

The range of response rates for Q13 to Q20 (shown in the Appendix), which measured the ease of accessing (i.e., M_Access) the various communication and collaboration functions in Moodle, varied from a low of approximately $52 \%$ for viewing Panopto (lecture capture) recordings to a high of $86 \%$ for completing assignments using Moodle. This resulted in an average score of approximately 4.0 out of 5.0 for the M_Access variable. Our final explanatory variable is labeled M_Comm, and it measured the ease of use of the common communication/collaboration tools in Moodle. The M_Comm, or the ease of communication measure, ranged from a low of approximately $17 \%$ for using the blog feature to a high of 53\% for sending messages via e-mail (see Appendix). This probably reflects the student expectation that, with online courses, instructors will use numerous advanced access features (e.g., forums, blogs, and chats) rather than simply communicating via e-mails. Hence, this resulted in the lowest score of 3.3 for the M_Comm variable. The highest score of 3.9 out of 5.0 was for the M_Exp measure, which is attributable to the students' experience (e.g., straightforward, easy to navigate, able to complete assignments, and interact and do things) with Moodle.

Table 3 shows that students' overall satisfaction with using Moodle was significantly and negatively correlated at the $\mathrm{p}<0.01$ level with all our explanatory variables M_Assess, M_Access, M_Comm, and M_Exp. A lower score for the overall satisfaction dependent variable refers to greater satisfaction, and a higher score for the explanatory variables refers to greater ease of use of using the functionality in Moodle. Thus, the significant negative relationship suggests that the higher the score for the explanatory variable, the greater the level of satisfaction with Moodle. Table 3 also shows that the student's class standing may be an important control variable. Our summer course data suggests that freshmen and sophomore students may be more comfortable with the assessment and access functionalities of Moodle as compared to juniors, seniors, and graduate students; this is possibly explained by older students' having to "unlearn" the previous campus LMS. This finding may also reflect the fact that freshmen and sophomore students have greater familiarity with the technology and are not influenced by their past experiences in face-to-face courses. 
Table 3. Person correlation coefficients

\begin{tabular}{|c|c|c|c|c|c|c|c|c|c|}
\hline Variable & Train & M_Assess & M_Access & M_Comm & M_Exp & Gender & Standing & GPA & College \\
\hline $\begin{array}{l}\text { Overall } \\
\text { Satisfaction }\end{array}$ & 0.02 & $-0.65^{* * * *}$ & $-0.74^{* * *}$ & $-0.60^{* * * *}$ & $-0.84^{* * *}$ & -0.01 & 0.16 & -0.0 & -0.16 \\
\hline Train & & -0.04 & 0.13 & 0.11 & 0.03 & 0.07 & -0.06 & -0.10 & 0.01 \\
\hline M_Assess & & & $0.64^{* * *}$ & $0.79^{* * * *}$ & $0.62^{* * *}$ & -0.12 & -0.14 & 0.03 & -0.05 \\
\hline M_Acess & & & & $0.76^{* * *}$ & $0.82^{* * *}$ & 0.10 & $-0.31^{* *}$ & 0.03 & 0.14 \\
\hline M_Comm & & & & & $0.72^{* * *}$ & 0.16 & $-0.44^{* *}$ & -0.01 & -0.16 \\
\hline M_Exp & & & & & & 0.05 & -0.20 & 0.07 & 0.14 \\
\hline Gender & & & & & & & -0.16 & $0.29^{* *}$ & 0.20 \\
\hline Standing & & & & & & & & -0.16 & -0.08 \\
\hline
\end{tabular}

Note. ***. Correlation is significant at the 0.01 level (2-tailed).

**. Correlation is significant at the 0.05 level (2-tailed).

The multivariate OLS regression analyses with M_Assess and Overall Satisfaction as the dependent variables are shown in Tables 4-5, respectively. Table 4 shows that the M_Assess variable is significantly and positively associated with the M_Comm variable, and that our model 1 explains $57 \%$ of the variance in M_Assess that is significant at the $\mathrm{p}<0.01$ level. This result suggests that using Moodle to do online assessment activities, such as providing feedback on assignments, is significantly and positively influenced by the extent to which instructors use the communication and collaboration tools (e.g., chat, blog, and Adobe Connect). Thus, we conclude that there is significant support for the hypothesis that using Moodle for assessment activities is significantly and positively associated with the instructors' familiarity with using the tools, particularly the advanced functionalities offered by the LMS.

Table 4. Regression of assessment in moodle (M_Assess) on explanatory variables and control variables

Note. Adjusted $\mathrm{R}^{2}=0.57$, Model's F stat 5.31 that is significant at the 0.002 level.

\begin{tabular}{ccccc}
\hline Variable & Beta & Std. Error & $\mathrm{t}$ & Sig. \\
\hline Constant & -0.10 & 1.91 & -0.05 & 0.96 \\
M_Access & 0.05 & 0.35 & 0.17 & 0.87 \\
M_Comm & $\mathbf{0 . 5 3}$ & $\mathbf{0 . 2 9}$ & $\mathbf{2 . 2 1}$ & $\mathbf{0 . 0 4}$ \\
M_Exp & 0.31 & 0.38 & 1.13 & 0.27 \\
Train & 0.06 & 0.43 & 0.42 & 0.68 \\
Gender & $\mathbf{- 0 . 2 5}$ & $\mathbf{0 . 3 9}$ & $\mathbf{- 1 . 6 9}$ & $\mathbf{0 . 1 0 *}$ \\
Standing & -0.06 & 0.20 & -0.40 & 0.69 \\
GPA & 0.07 & 0.22 & 0.48 & 0.64 \\
College & -0.01 & 0.10 & -0.01 & 0.99 \\
\hline
\end{tabular}

**. Correlation is significant at the 0.05 level.

*. Correlation is significant at the 0.10 level.

Table 5 shows that the Overall Satisfaction with using the Moodle LMS is significantly and negatively associated with the M_Exp variable, and that our model 2 explains $60 \%$ of the variance in the level of student satisfaction that is significant at the $\mathrm{p}<0.01$ level. This result suggests that the higher the positive experience with navigating the system, completing assignments, and interaction to do things in Moodle, the greater the overall student satisfaction. Thus, we conclude that there is significant support for the hypothesis that satisfaction with using Moodle for online learning is significantly influenced by the instructors' familiarity and knowledge about how best to structure the navigation of the courses in Moodle as well as the use of it to complete assignments. Hence, though Moodle might be an easy system for students to use, it is important to ensure that instructors learn how to set up their courses and use Moodle's communication and collaboration functionalities for assessment activities. 
Table 5. Regression of overall satisfaction with moodle on explanatory variables and control variables

\begin{tabular}{ccccc}
\hline Variable & Beta & Std. Error & T & Sig. \\
\hline Constant & $\mathbf{5 . 6 7}$ & $\mathbf{1 . 8 4}$ & $\mathbf{3 . 0 8}$ & $\mathbf{0 . 0 1 * *}$ \\
M_Assess & -0.03 & 0.23 & -0.11 & 0.91 \\
M_Access & 0.03 & 0.34 & 0.12 & 0.91 \\
M_Comm & 0.03 & 0.32 & 0.09 & 0.93 \\
M_Exp & $\mathbf{- 0 . 9 0}$ & $\mathbf{0 . 3 8}$ & $\mathbf{- 3 . 3 0}$ & $\mathbf{0 . 0 0 * *}$ \\
Train & 0.05 & 0.41 & 0.34 & 0.74 \\
Gender & 0.14 & 0.41 & 0.93 & 0.37 \\
Standing & 0.04 & 0.19 & 0.30 & 0.77 \\
GPA & 0.05 & 0.22 & 0.35 & 0.73 \\
College & -0.05 & 0.10 & -0.38 & 0.71 \\
\hline
\end{tabular}

Note. Adjusted $\mathrm{R}^{2}=0.60$, model's $\mathrm{F}$ stat 5.38 that is significant at 0.001 level.

***. Correlation is significant at the 0.01 level.

\subsection{Quantitative Data-Faculty Survey Close-Ended Questions}

In addition to a survey sent to students who were taking an online or hybrid courses using Moodle, we also sent out a survey to faculty members who were instructors teaching those courses. 17 of the 22 instructors completed the survey, with a $77.3 \%$ response rate. Since the total number of the faculty respondents are not large enough to do more in-depth data analysis as we did for the student survey, we include here some basic data in order to show the instructor's perspective and compare with the results from the student's survey.

In comparing students' perceptions and use of Moodle with that of the 17 faculty members, we found that faculty members felt the Moodle interface was straightforward (50\%), easy to navigate (80\%), and satisfactory to create class assignments (81\%). Of the faculty members, $82 \%$ had been trained to use the LMS. Additionally, no one was dissatisfied after using Moodle during summer semesters when the survey was conducted, which was the first time that online courses were offered by this university. When we examined a specific cross-section (faculty not trained), the findings were similar to those who had received training. In terms of the more assessment-based and interactive/collaborative activities within Moodle, faculty reported less frequent use than did students of Moodle assignments (63\%), Turnitin assignments (35\%), graded discussion forums (35\%), messages (35\%), wikis $(34 \%)$, quizzes $(29 \%)$, chats $(29 \%)$, and blogs $(6 \%)$. However, $100 \%$ of instructors were 1) comfortable with Moodle, 2) able to add their syllabi and make their courses available, and 3) able to easily upload files and content to their sites. Additionally, $94 \%$ felt they were able to communicate effectively with their students using Moodle. These four areas were focal points for the university when providing professional development to the faculty.

Instructors were less likely to use more advanced functions of the LMS (e.g., Turnitin assignments, graded forum discussions, quizzes, chats, and blogs), beyond those basic functions in which they received training. Hence, this faculty finding further supports our hypothesis that using Moodle for assessment activities is significantly and positively associated with the instructors' familiarity with using such tools, particularly the advanced functionalities offered by the system. Furthermore, there is support for the hypothesis that satisfaction with using Moodle for online learning is significantly influenced by the instructors' familiarity and knowledge about how best to structure the navigation of the courses in Moodle and use it to complete assignments. Therefore, though Moodle might be an easy system for students to use, it is important to ensure that instructors learn how to set up their courses and use Moodle's communication and collaboration functionalities for assessment activities.

\subsection{Qualitative Data-the Student Open-Ended Question}

The study also collected some qualitative data from students. There is an open ended question in the end of the student survey: 'Please comment briefly on your experience with Moodle' that seek additional qualitative data regarding students' online learning experience use Moodle as the LMS. It provided some insight and detailed descriptions of the student's experiences that were hard to capture using close-ended survey questions. This is one of the major reasons that we give students the opportunities to provide the written comments. Only 4 students from the survey did not provide additional comments for this question ( 2 left it blank, 1 wrote 'N/A', and 1 wrote 'None'). The written comments were from a few words to a paragraph. In order to provide the clear qualitative data analysis, we broke the longer comments into different parts where they covered different themes. Therefore, in the analysis below, one students' comment might be represented in different sections. We 
categorized the written comments into two big categories: Positive and negative; in addition, we also divided comments into 5 different levels: Very poor, poor, OK, good, and very good.

For the overall experience of using Moodle, most of the comments are positive in nature, ranged from OK to very good. The examples for 'OK' comments are: "Did not experience significant issues", and "It was fine". The examples for 'good' and 'very good' comments are: "Moodle was very organized and easy for me to use", "It was a pleasant experience", and "Very helpful." This is consistent with the quantitative data where high percentage of the students are satisfied with using Moodle.

The written comments also pointed out some issues with using Moodle as LMS. Many of those issues are negative in nature, student's perceptions of their experience were 'poor' or 'very poor'. Those negative experiences included general issues and more specific issues. For general issues with using Moodle as LMS, students had comments like: "Sometimes Moodle does not want to work for the students and I think that the teachers sometimes have difficulty with using it as well." "needs some more organization. still a little confused with it." "I thought Moodle was very unorganized and found it extremely hard to find things on the website." For specific issues, difficulty with certain functionalities were very common, for example: "I have no idea how to find my grades." "navigation sucks; it's too hard to go back to the place you just were." "we have had great difficulty with sending in assignments." "The Ponopto recordings were not clear. This made the lectures almost impossible to understand." "Using adobe connect was very hard and I was never able to get it to work."

From the students' written comments, past experience of using Moodle seems to be a contributing factor to the students' perceptions of their experience of using it as LMS. When students have used Moodle before, either professionally or academically, their perceptions of the experiences of using Moodle for the summer online/hybrid courses at the university where the research is conducted, seems to be very positive. Students had comments like: "I have used Moodle in every semester I have been at xxx (the university). It has become easy for me to use and I am comfortable using it." "I used Moodle in high school, so I really did not have any problems with it." "I've used Moodle in my professional career before using it at xxx (the university) making the experience of using it at xxx (the university) very simple." And "I had the opportunity to use Moodle while teaching an online course myself. It was incredibly easy and I was able to personalize it as much as I wanted." Similarly, a recent study by Chang et al. showed students with high internet self-efficiency outperformed those with low internet self-efficiency on the final exam and have more confidence in their ability to complete an online course (Chang et al., 2014). Another study's results also indicated that students with more experience of online learning are more satisfied with their online course delivery medium (Arbaugh \& Duray, 2002). Overall, the influence of past experience of using technology, software and the systems seems to be a factor that impact users' perceptions of their experience of using a particular system as online learning platform.

There is one particular theme that is very clear from the student comments, that is the professor's readiness and familiarity to use Moodle had great influence with students' experience with it, both positively and negatively. Examples students comments are: "Some instructors have more experience with it and therefore their course material is easier to obtain" "several times during my course, issues with students/the professor not understanding an aspect of moodle led to confusion and disagreement." "It is often difficult to navigate and find links and assignment when professors don't know how to set it up in an understandable fashion." One student could have different experiences using Moodle, based upon the different levels of readiness and effectiveness of the instructors setting up the courses. The following comments from one student may demonstrate this: "I have taken 1 Moodle intensive in-classroom course and 1 hybrid course that could not have functioned without high Moodle use; both professors were exceptional at Moodle set up and instruction. I took 1 course in which the professor attempted to use Moodle but his lack of knowledge of the project was not the level he wanted it to be which made the material difficult for me access and understand." The following students' comments could probably summarize the importance of the instructor's knowledge and ability to effectively using Moodle, and its impact on students' experience: "I don't feel Moodle is used as well by professors as it could be. I think if the professors utilized it more, it would be better or easier for students to navigate." "It definitely depends on how the instructor uses the site-the more the instructor knows about Moodle the better. Unfortunately, there seems to be a big disconnect from professor to professor and their abilities to teach online."

There are some written comments that were not common, but related to issues that would not otherwise be captured by the close-ended questions form the survey. Examples include such concerns as the online course itself: "I am all for having a software that assists with the effectiveness of a course, but I do not agree with a course that is fully taught online. It is absurd to believe that a student can receive the same in-class experience in a virtual setting." The student made this comment is the type of the students that needs more personal interaction and affiliation, and does not believe online course would deliver the same experience as a face-to-face course. 
This type of student's concerns is supported by a recent study which showed that the need for affiliation plays a significant role in online satisfaction, higher the need for affiliation less the likelihood that the student would take another online course (Seiver \& Troja, 2014).

Written comments confirmed some of the findings from the quantitative data analysis results, such as the overall positive experience with using Moodle. It helped finding more detailed information for certain issues that could not be completely captured by the close-ended questions. Furthermore, the analysis of the written comments revealed some aspects that would help to form additions and modifications for future studies.

\section{Limitation}

The major limitation of the study is the fact that the sample included only a single university where the students had the option to take the class on-line or face-to-face. Thus, those who chose to do the course on-line might be biased sample that already values such a mode for delivering the course. Another limitation is that we only tested one learning management system, and future research might consider the student satisfaction using multiple on-line systems with a variety of functionalities including assessment capabilities.

\section{Conclusion}

This study is based on a survey of students who took online or hybrid course sections during the summer term at a US university and of the instructors who were teaching those courses. Students who took the survey found the Moodle interface straightforward, easy to navigate, and satisfactory for completing assignments, despite only $18 \%$ being trained to use it. Additionally, only $11 \%$ of the students were dissatisfied after using Moodle. Acceptance of an online learning system and cognitive absorption are important variables in the TAM model that explains user satisfaction (Saade \& Bahli, 2005). Hence, the fact that Moodle was an easy system to use, it was widely accepted, and student with greater involvement in their learning had greater satisfaction in our study too.

We find support for the hypothesis that overall student satisfaction with online learning is significantly affected by how the course is organized and how the content is sequenced, the ease with which students can complete assignments, and the use of the LMS to engage with content (rather than simply read or view it). Further, when we examined students' responses across the colleges, comparing the responses from an introductory accounting course offered by the College of Business versus the other colleges, the responses were similar. Additionally, there was no difference between those students who received training versus those who did not receive Moodle training. Thus, we decided to combine all the student responses from the different colleges and examine what factors led to successful online assessment activities.

Faculty survey results also supported the basic findings from the student survey from a different perspective. Interestingly, no faculty was dissatisfied with using Moodle as the LMS platform for teaching online courses, which was the first time that online courses were offered by the university. The open-ended question from the student survey provided more vivid descriptions of the students' experience of using Moodle. It not only offered more insight and detailed information that confirmed the findings from the close-ended questions, but also helped in discovering aspects should be further investigated by future studies.

In summary, we find support for the hypothesis that satisfaction with online assessment is significantly and positively influenced by students' being able to view grades, access feedback, and view comments to their submitted assignments. We also conclude that students' satisfaction with using Moodle for online learning is significantly influenced by the instructors' familiarity and knowledge about how to utilize Moodle as the platform of LMS.

\section{References}

Allen, I. E., \& Seaman, J. (2013). Changing course: Ten years of tracking online education in the United States. Sloan Consortium, 43(3), 47.

Alwi, N. H. M., \& Fan, I. S. (2010). E-learning and information security management. International Journal of Digital Society, 1(2), 148-156.

Anderson, T., Rourke, L., Garrison, D., \& Archer, W. (2001). Assessing teaching presence in a computer conferencing context. Journal of Asynchronous Learning Networks, 5(2), 1-17.

Arbaugh, J. B., \& Duray, R. (2002). Technological and Structural Characteristics, Student Learning and Satisfaction with Web-Based Courses: An Exploratory Study of Two On-Line MBA Programs. Management Learning, 33(3), 331-347. http://dx.doi.org/10.1177/1350507602333003

Baran, E., Correia, A. P., \& Thompson, A. (2011). Transforming online teaching practice: Critical analysis of the literature on the roles and competencies of online teachers. Distance Education, 32(3), 421-439. 
http://dx.doi.org/10.1080/01587919.2011.610293

Bell, B. S., \& Federman, J. E. (2013). E-learning in postsecondary education. The Future of Children, 23(1), 165-185. http://dx.doi.org/10.1353/foc.2013.0007

Berge, Z. (2009). Changing instructor's roles in virtual worlds. Quarterly Review of Distance Education, 9(4), 407-415.

Berge, Z., \& Collins, M. (2000). Perceptions of e-moderators about their roles and functions in moderating electronic mailing lists. Distance Education, 21(1), 81-100. http://dx.doi.org/10.1080/0158791000210106

Chang, C.-S., Liu, E. Z. F., Sung, H. Y., Lin, C. H., Chen, N. S., \& Cheng, S. S. (2014). Effects of online college student's Internet self-efficacy on learning motivation and performance. Innovations in Education and Teaching International, 51(4), 366-377. http://dx.doi.org/10.1080/14703297.2013.771429

Coppola, C., \& Neelley, E. (2004). Open source-opens learning: Why open source makes sense for education. Retrieved from http://www.rsmart.com

Dahl, S. (2007). Turnitin ${ }^{\circledR}$ The student perspective on using plagiarism detection software. Active Learning in Higher Education, 8(2), 173-191. http://dx.doi.org/10.1177/1469787407074110

Dermo, J. (2009). E-Assessment and the student learning experience: A survey of student perceptions of e-assessment. British Journal of Educational Technology, 40(2), 203-214. http://dx.doi.org/10.1111/j.1467-8535.2008.00915.x

Eom, S. B., Wen, H. J., \& Ashill, N. (2006). The determinants of students' perceived learning outcomes and satisfaction in university online education: An empirical investigation. Decision Sciences Journal of Innovative Education, 4(2), 215-235. http://dx.doi.org/10.1111/j.1540-4609.2006.00114.x

Georgouli, K., Skalkidis, I., \& Guerreiro, P. (2008). A Framework for Adopting LMS to Introduce e-Learning in a Traditional Course. Educational Technology \& Society, 11(2), 227-240.

Goodyear, P., Salmon, G., Spector, J. M., Steeples, C., \& Tickner, S. (2001). Competences for online teaching: A special report. Educational Technology Research and Development, 49(1), 65-72. http://dx.doi.org/10.1007/BF02504508

Graham, C., Cagiltay, K., Lim, B. R., Craner, J., \& Duffy, T. (2001). Seven principles of effective teaching: A practical lens for evaluating online courses. The Technology Source. Retrieved from http://www.technologysource.org/article/seven_principles_of_effective_teaching/

Guasch, T., Alvarez, I., \& Espasa, A. (2010). University teacher competencies in a virtual teaching/learning environment: Analysis of a teacher training experience. Teaching and Teacher Education, 26(2), 199-206. http://dx.doi.org/10.1016/j.tate.2009.02.018

Hollenbeck, C. R., \& Mason, C. H. (2011). Enhancing student learning in marketing courses: An exploration of fundamental principles for website platforms. Journal of Marketing Education, 33(2), 171-182. http://dx.doi.org/10.1177/0273475311410850

King, C. G., Guyette, R. W., \& Piotrowski, C. (2009). Online exams and cheating: An empirical analysis of business students' views. The Journal of Educators Online, 6(1-11).

Kuo, Y. C., Walker, A. E., Belland, B. R., Schroder, K. E. E., \& Kuo, Y. T. (2014). A case study of integrating interwise: Interaction, internet self-efficacy, and satisfaction in synchronous online learning environments. The International Review of Research in Open and Distributed Learning, 15(1).

Naveh, G., Pliskin, N., \& Tubin, D. (2010). Student LMS use and satisfaction in academic institutions: The organizational perspective. The Internet and Higher Education, 13(3), 127-133. http://dx.doi.org/10.1016/j.iheduc.2010.02.004

ODCD. (2005). E-learning in tertiary education, Policy brief. OECD Observer. Retrieved from http://www.oecd.org

Oncu, S., \& Cakir, H. (2011). Research in online learning environments: Priorities and methodologies. Computers \& Education, 57, 1098-1108. http://dx.doi.org/10.1016/j.compedu.2010.12.009

Puzziferro, M., \& Shelton, K. (2008). A model for developing high-quality online courses: Integrating a systems approach with learning theory. Journal of Asynchronous Learning Networks, 12(3-4), 119-136.

Reeves, T., C. (2000). Alternative assessment approaches for online learning environments in higher education. Journal of Educational Computing Research, 23(1), 101-111. 
http://dx.doi.org/10.2190/GYMQ-78FA-WMTX-J06C

Saade, R., \& Bahli, B. (2005). The impact of cognitive absorption on perceived usefulness and perceived ease of use in on-line learning: An extension of the technology acceptance model. Information \& Management, 42(2), 317-327. http://dx.doi.org/10.1016/j.im.2003.12.013

Salmon, G. (2004). E-moderating: The key to teaching and learning online. London: RoutledgeFalmer.

Schroder, K. E. E., \& Belland, B. R. (2014). Interaction, Internet self-efficacy, and self-regulated learning as predictors of student satisfaction in online education courses. The Internet and Higher Education, 20, $35-50$.

Schrum, L., \& Hong, S. (2002). Dimensions and strategies for online success: Voices from experienced educators. Journal of Asynchronous Learning Networks, 6(1), 57-67. Retrieved from http://sloanconsortium.org/sites/default/files/v6n1_schrum_1.pdf

Seiver, J. G., \& Troja, A. (2014). Satisfaction and success in online learning as a function of the needs for affiliation, autonomy, and mastery. Distance Education, 35(1), 90-105. http://dx.doi.org/10.1080/01587919.2014.891427

Selim, H. M. (2005). Critical success factors for e-learning acceptance: Confirmatory factor models. Computers \& Education, 49(2), 396-413. http://dx.doi.org/10.1016/j.compedu.2005.09.004

Smith, T. (2005). Fifty-one competencies for online instruction. The Journal of Educators Online, 2(2), 1-18. Retrieved from http://www.thejeo.com/Archives/Volume2Number2/SmithFinal.pdf

Stacey, E., \& Wiesenberg, F. P. (2008). Teaching philosophy: Moving from face-to-face to online classrooms. Canadian Journal of University Continuing Education, 34(1), 63-79.

Sun, P. C., Tsai, R. J., Finger, G., Chen, Y. Y., \& Yeh, D. (2008). What drives a successful e-Learning? An empirical investigation of the critical factors influencing learner satisfaction. Computers \& Education, 50, 1183-1202. http://dx.doi.org/10.1016/j.compedu.2006.11.007

Sutherland-Smith, W., \& Carr, R. (2005). Turnitin.com: Teachers' perspectives of anti-plagiarism software in raising issues of educational integrity. Journal of University Teaching \& Learning Practice, 2(3).

Williams, R. (2003). Integrating distributed learning with just-in-content knowledge management. Electronic Journal of e-Learning, 1(1), 45-50.

\section{Appendix}

Questionnaire

Q1. Indicate your gender

- $\quad$ Male $=1(23.1 \%)$

- $\quad$ Female $=2(69.1 \%)$

Q2. Indicate your current standing

$$
\begin{array}{ll}
\text { - } & \text { Freshmen }=1(2.2 \%) \\
\text { - } & \text { Sophomore }=2(41.8 \%) \\
\text { - } & \text { Junior }=3(22.0 \%) \\
\text { - } & \text { Senior }=4(30.8 \%) \\
\hline & \text { Graduate }=5(3.3 \%)
\end{array}
$$

Q3. Please indicate which college(s) you are affiliated

- College of Business $=1(24.2 \%)$

- College of Communication $=2(7.7 \%)$

- College of Education = $3(27.5 \%)$

- College of Liberal Arts \& Sciences $=4(28.6 \%)$

- $\quad$ College of Pharmacy \& Health Sciences $=5(12.1 \%)$

- Not Applicable (Not Sure?) $=6(3.3 \%)$ 
Q4. Indicate your current GPA?

- Less than $1.50=1(0.0 \%)$

- $\quad 1.50-2.00=2(0.0 \%)$

- $2.00-2.50=3(5.5 \%)$

- $\quad 2.50-3.00=4(8.8 \%)$

- $3.00-3.50=5(19.8 \%)$

- $\quad 3.50-4.00=6(65.9 \%)$

Q5. How many courses are you enrolled for the term?

- $\quad$ None $=1(0.0 \%)$

- $\quad$ One $=2(41.8 \%)$

- $\quad$ Two $=3(31.9 \%)$

- $\quad$ Three $=4(9.9 \%)$

- $\quad$ Four $=5(12.1 \%)$

- $\quad$ Five or more $=6(4.4 \%)$

Q6. How important is the use of Moodle for your course?

- $\quad$ Very Important $=1(95.3 \%)$

- $\quad$ Somewhat Important $=2(4.4 \%)$

- $\quad$ Not Important $=3(0.0 \%)$

Q7. How many semesters have you utilized Moodle for a course at the University?

- $\quad$ None $=1(7.7 \%)$

- One $=2(11.0 \%)$

- $\quad$ Two $=3(40.7 \%)$

- $\quad$ Three $=4(22.0 \%)$

- $\quad$ Four $=5(18.7 \%)$

Training (Train)

Q8. Did you receive an orientation or training before using Moodle? (Orient_M)

- $\quad$ Yes $=1(17.6 \%)$

- $\quad$ No $=2(79.1 \%)$

- $\quad \mathrm{NA}=2(3.3 \%)$

Q9. If you received Moodle orientation or training, do you feel it was adequate for your needs? (Adeq_Orient)

- $\quad$ Yes $=1(20.9 \%)$

- $\quad$ No $=2(5.5 \%)$

- $\quad \mathrm{NA}=2(73.6 \%)$

Online Assessment (M_Assess)

Q10. Viewing your grades: (View_Grade_M)

- $\quad$ Very difficult to use $=1(7.7 \%)$

- $\quad$ Difficult to use $=2(14.3 \%)$

- $\quad$ Neutral $=3(12.1 \%)$

- $\quad$ Easy to use $=4(25.3 \%)$

- $\quad$ Very Easy to use $=5(37.4 \%)$

- NA (3.3\%)

Q11. Accessing feedback with Moodle Assignments: (Access_Feed_M) 
- $\quad$ Very difficult to use $=1(6.6 \%)$

- $\quad$ Difficult to use $=2(16.5 \%)$

- $\quad$ Neutral $=3(16.5 \%)$

- $\quad$ Easy to use $=4(38.5 \%)$

- $\quad$ Very Easy to use $=5(18.7 \%)$

- NA(3.3\%)

Q12. Viewing comments within Turnitin Assignments: (Turnit_Comment)

- $\quad$ Very difficult to use $=1(5.5 \%)$

- $\quad$ Difficult to use $=2(17.6 \%)$

- $\quad$ Neutral $=3(14.3 \%)$

- $\quad$ Easy to use $=4(26.4 \%)$

- $\quad$ Very Easy to use $=5(17.6 \%)$

- $\quad$ NA (18.7\%)

Course Content (M_Access)

Q13. Viewing Files/Folders (View_Folder_M)

- $\quad$ Very difficult to use $=1(2.2 \%)$

- $\quad$ Difficult to use $=2(3.3 \%)$

- $\quad$ Neutral $=3(17.6 \%)$

- $\quad$ Easy to use $=4(44.0 \%)$

- $\quad$ Very Easy to use $=5(31.9 \%)$

- NA (1.1\%)

Q14. Viewing Links to Websites (View_Web_M)

- $\quad$ Very difficult to use $=1(2.2 \%)$

- $\quad$ Difficult to use $=2(4.4 \%)$

- $\quad$ Neutral $=3(15.4 \%)$

- $\quad$ Easy to use $=4(42.9 \%)$

- $\quad$ Very Easy to use $=5(34.1 \%)$

- NA(1.1\%)

Q15. Completing Assignments: (Compl_Assign_M)

- $\quad$ Very difficult to use $=1(1.1 \%)$

- $\quad$ Difficult to use $=2(5.5 \%)$

- $\quad$ Neutral $=3(6.6 \%)$

- $\quad$ Easy to use $=4(41.8 \%)$

- $\quad$ Very Easy to use $=5(44.0 \%)$

- NA(1.1\%)

Q16. Completing Turnitin Assignments: (Compl_Turnit)

- $\quad$ Very difficult to use $=1(2.2 \%)$

- $\quad$ Difficult to use $=2(4.4 \%)$

- $\quad$ Neutral $=3(15.4 \%)$

- $\quad$ Easy to use $=4(42.9 \%)$

- $\quad$ Very Easy to use $=5(34.1 \%)$

- NA (1.1\%) 
Q17. Viewing Panopto recordings: (View_Panapto)

- $\quad$ Very difficult to use $=1(5.5 \%)$

- $\quad$ Difficult to use $=2(9.9 \%)$

- $\quad$ Neutral $=3(12.1 \%)$

- $\quad$ Easy to use $=4(27.5 \%)$

- Very Easy to use $=5(24.2 \%)$

- NA (20.9\%)

Q18. Taking Quizzes: (Take_Quiz_M)

- $\quad$ Very difficult to use $=1(1.1 \%)$

- $\quad$ Difficult to use $=2(6.6 \%)$

- $\quad$ Neutral $=3(5.5 \%)$

- $\quad$ Easy to use $=4(36.3 \%)$

- $\quad$ Very Easy to use $=5(27.5 \%)$

- NA (23.1\%)

Q19. News Forum (Announcements) (News_Forum)

- $\quad$ Very difficult to use $=1(3.3 \%)$

- $\quad$ Difficult to use $=2(9.9 \%)$

- $\quad$ Neutral $=3(15.4 \%)$

- $\quad$ Easy to use $=4(30.8 \%)$

- $\quad$ Very Easy to use $=5(24.2 \%)$

- NA (16.5\%)

Q20. Forums (Discussion Board): (Discuss_M)

- $\quad$ Very difficult to use $=1(2.2 \%)$

- $\quad$ Difficult to use $=2(12.1 \%)$

- $\quad$ Neutral $=3(13.2 \%)$

- $\quad$ Easy to use $=4(34.1 \%)$

- $\quad$ Very Easy to use $=5(30.8 \%)$

- NA(7.7\%)

Communication and Collaboration (M_Comm)

Q21. Messages (IIM/Email): (Email_M)

- $\quad$ Very difficult to use $=1(2.2 \%)$

- $\quad$ Difficult to use $=2(12.1 \%)$

- $\quad$ Neutral $=3(19.8 \%)$

- $\quad$ Easy to use $=4(26.4 \%)$

- $\quad$ Very Easy to use $=5(26.4 \%)$

- $\quad$ NA (13.2\%)

Q22. Chat: (Chat_M)

- Very difficult to use $=1(2.2 \%)$

- $\quad$ Difficult to use $=2(8.9 \%)$

- $\quad$ Neutral $=3(15.6 \%)$

- $\quad$ Easy to use $=4(8.9 \%)$

- $\quad$ Very Easy to use $=5(7.8 \%)$ 
- $\quad$ NA (56.7\%)

Q23. Wiki: (Wiki_M)

- $\quad$ Very difficult to use $=1(1.1 \%)$

- $\quad$ Difficult to use $=2(6.6 \%)$

- $\quad$ Neutral $=3(18.7 \%)$

- $\quad$ Easy to use $=4(13.2 \%)$

- $\quad$ Very Easy to use $=5(9.9 \%)$

- NA (50.5\%)

Q24. Blog (Blog_M)

- $\quad$ Very difficult to use $=1(1.1 \%)$

- $\quad$ Difficult to use $=2(5.5 \%)$

- $\quad$ Neutral $=3(17.6 \%)$

- $\quad$ Easy to use $=4(9.9 \%)$

- $\quad$ Very Easy to use $=5(8.8 \%)$

- NA (57.1\%)

Q25. Adobe Connect (Adobe_Conn)

- $\quad$ Very difficult to use $=1(5.5 \%)$

- $\quad$ Difficult to use $=2(6.6 \%)$

- $\quad$ Neutral $=3(15.4 \%)$

- $\quad$ Easy to use $=4(12.1 \%)$

- $\quad$ Very Easy to use $=5(12.1 \%)$

- NA (48.4\%)

Overall Moodle Experience (M_Experience)

Q26. Moodle is straight forward and easy: (Straight_Forward)

- $\quad$ Strongly Disagree $=1(4.5 \%)$

- $\quad$ Disagree $=2(10.2 \%)$

- $\quad$ Neutral $=3(17.0 \%)$

- $\quad$ Agree $=4(36.4 \%)$

- $\quad$ Strongly Agree $=5(31.8 \%)$

Q27. The organization and sequence of course was easy to navigate: (Course_Seq_Navigate)

- $\quad$ Strongly Disagree $=1(1.1 \%)$

- $\quad$ Disagree $=2(8.0 \%)$

- $\quad$ Neutral $=3(19.3 \%)$

- $\quad$ Agree $=4(36.4 \%)$

- $\quad$ Strongly Agree $=5(35.2 \%)$

Q28. I am able to complete class assignments in Moodle: (Compl_Assign)

- $\quad$ Strongly Disagree $=1(0.0 \%)$

- $\quad$ Disagree $=2(1.1 \%)$

- $\quad$ Neutral $=3(9.0 \%)$

- $\quad$ Agree $=4(42.7 \%)$

- $\quad$ Strongly Agree $=5(47.2 \%)$

Q29. In the majority of my courses, I INTERACT and DO THINGS with content rather than READ/VIEW the content: (Interact_Do_Things) 
- $\quad$ Strongly Disagree $=1(5.6 \%)$

- $\quad$ Disagree $=2(5.6 \%)$

- $\quad$ Neutral $=3(38.2 \%)$

- $\quad$ Agree $=4(29.2 \%)$

- $\quad$ Strongly Agree $=5(21.3 \%)$

Q30. What is your overall satisfaction with Moodle? (Satisfy)

- $\quad$ Very Satisfied $=1(28.1 \%)$

- $\quad$ Satisfied $=2(42.7 \%)$

- $\quad$ Neutral $=3(18.0 \%)$

- $\quad$ Dissatisfied $=4(7.9 \%)$

- $\quad$ Very Dissatisfied $=5(3.4 \%)$

\section{Copyrights}

Copyright for this article is retained by the author(s), with first publication rights granted to the journal.

This is an open-access article distributed under the terms and conditions of the Creative Commons Attribution license (http://creativecommons.org/licenses/by/3.0/). 